\title{
PENGARUH PENDEKATAN REALISTIC MATHEMATIC EDUCATION (RME) TERHADAP KEMAMPUAN PEMAHAMAN KONSEP SISWA KELAS VIII SMP
}

\begin{abstract}
Abstrak
Penelitian ini bertujuan untuk mengetahui pengaruh pendekatan RME terhadap kemampuan pemahaman konsep matematis siswa. Jenis penelitian ini adalah Quasy Eksperiment. Populasi pada penelitian ini adalah siswa kelas VIII SMP N 1 Hiliserangkai Tahun Pelajaran 2019/2020. Sampel penelitian ini yaitu siswa kelas VIIIA dan siswa kelas VIIIC. Data penelitian diperoleh dari hasil tes kemampuan awal dan tes akhir berupa soal kemampuan pemahanan konsep. Analisis data dilakukan menggunakan uji t dan Mann-Whitney U. Berdasarkan hasil analisis data dan pembahasan, diperoleh bahwa kemampuan pemahaman konsep matematis siswa yang mengikuti pembelajaran dengan pendekatan RME lebih tinggi dari siswa yang mengikuti pembelajaran konvensional. Pemahaman konsep matematis siswa berkemampuan awal tinggi yang mengikuti pembelajaran dengan pendekatan RME sama dengan siswa yang mengikuti pembelajaran konvensional. Pemahaman konsep siswa berkemampuan awal sedang dan rendah yang mengikuti pembelajaran dengan pendekatan RME lebih tinggi dari siswa yang mengikuti pembelajaran konvensional.
\end{abstract}

Kata Kunci: Pengaruh, Realistic Mathematic Education, Pemahaman Konsep.

\begin{abstract}
This study aims to determine the effect of the RME approach on students' ability to understand mathematical concepts. This type of research is Quasi Experiment. The population in this study were students of class VIII SMP N 1 Hiliserangkai Academic Year 2019/2020. The samples of this study were students of class VIIA and class VIIIC. The research data were obtained from the results of the initial ability test and the final test in the form of the ability to understand concepts. Data analysis was performed using t-test and Mann-Whitney U. Based on the results of data analysis and discussion, it was found that the ability to understand mathematical concepts of students who took learning with the RME approach was higher than students who took conventional learning. Understanding the mathematical concepts of students with high initial abilities who take learning with the RME approach is the same as students who take conventional learning. Understanding the concept of students with moderate and low initial abilities who take learning with the RME approach is higher than students who take conventional learning.
\end{abstract}

Keywords: Influence, Realistic Mathematic Education, Mathematical Concept Understanding.

\footnotetext{
${ }^{1}$ Prodi : Pendidikan Matematika, IKIP Gunung Sitoli

Email : sadianalase01@gmail.com
} 


\section{PENDAHULUAN}

Matematika merupakan salah satu ilmu dasar yang penting bagi kemajuan pendidikan dan teknologi yang yang bermanafaat bagi perkembangan bangsa. Secara umum pendidikan matematika bertujuan untuk mendidik dan memperluas pengetahuan, pengalaman dan wawasan manusia. Hal ini menunjukkan bahwa pendidikan merupakan proses yang disengaja, tertib dan berkesinambungan yang mengarah pada sasaran tertentu. (Dakhi, dkk., 2020; Fajra, dkk., 2020; Masril, dkk., 2020; Zagoto \& Dakhi, 2018). Kualitas proses menentukan hasil dari proses tersebut. Oleh karena itu, keterampilan matematika perlu lebih ditingkatkan, dan matematika secara umum dianggap sebagai mata pelajaran yang sulit, abstrak, dan penuh tekanan oleh siswa. Selain itu, proses pembelajaran yang dilakukan guru di kelas adalah pembelajaran mekanistik. Guru hanya memberikan informasi dan mengharapkan siswa untuk menghafal dan mengingat apa yang telah dipelajari siswa, memberikan kesempatan kepada siswa untuk berdiskusi dengan teman sekelas dan membuat siswa terlihat aktif dalam peroses pembelajaran, sehingga terkesan guru lebih aktif dari pada siswa.

Depdiknas (2006) melalui Permendiknas No. 22 tentang Standar Isi, tujuan pelajaran matematika di SD/MI, SMP/MTs, SMA/MA, dan SMK/MAK diantaranya adalah:

1. Memahami konsep matematika, menjelaskan hubungan di antara keduanya, dan menerapkan konsep atau log untuk memecahkan masalah secara fleksibel, akurat, efisien, dan akurat.

2. Kemampuan memahami dan merancang model matematika, memecahkan model, dan memecahkan masalah, termasuk kemampuan menerjemahkan solusi yang diperoleh.

3. Sikap menilai kegunaan matematika dalam kehidupan: rasa ingin tahu, minat, minat belajar matematika, ketahanan dan percaya diri saat memecahkan masalah.

Berdasarkan kutipan di atas, pemahaman konsep matematis merupakan salah satu kemampuan yang harus dimiliki oleh siswa dalam pembelajaran Terkuasainya konsep akan melatih siswa dalam memecahkan masalah matematis. Rendahnya hasil belajar siswa tersebut diduga karena pemahaman konsep matematis siswa yang masih rendah. Bukti yang bisa diberikan sehubungan dengan masalah tersebut adalah banyaknya siswa yang menjawab salah ketika diberikan soal pemahaman konsep. Dari tes yang diberikan, diperoleh 72, $8 \%$ jawaban siswa salah. Berikut ini adalah salah satu soal dan jawaban siswa tentang soal pemahaman konsep:

Jari-jari Lingkaran pertama $14 \mathrm{~cm}$. Hitunglah luas lingkaran kedua yang panjang jarijarinya 2 kali jari- jari lingkaran pertama. $\pi=\frac{22}{7}$

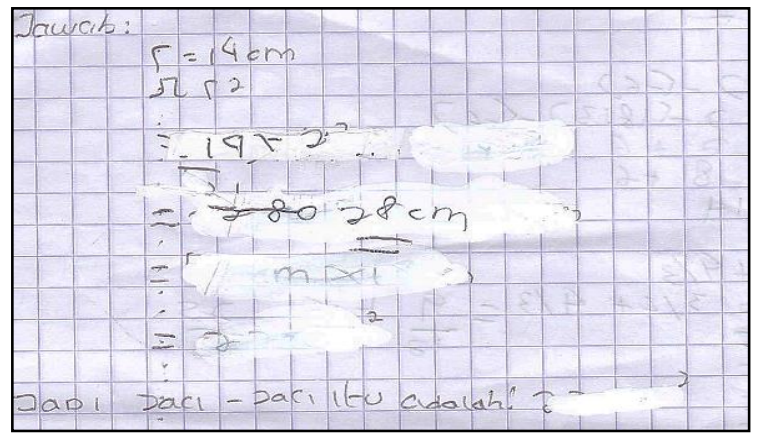

(a)

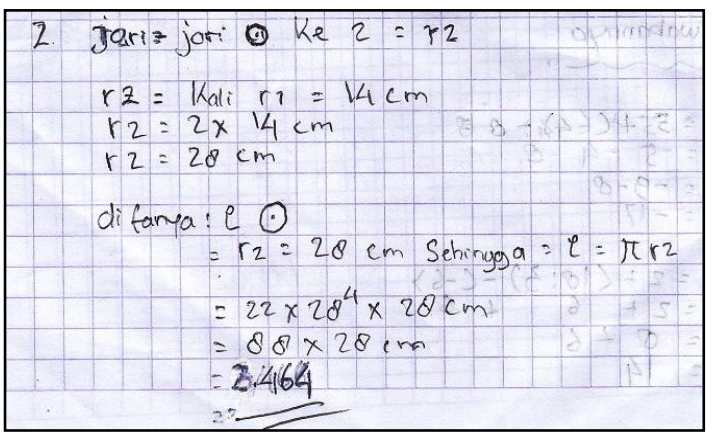

(b)

Gambar 1. Lembar Jawaban Siswa pada Soal Tes Pemahaman Konsep.

Berdasarkan jawaban siswa pada Gambar 1a, terlihat siswa tidak tahu bagaimana menyelasaikan soal tersebut. Pada Gambar 1b, siswa masih belum mampu menjawab soal dengan benar. Beberapa siswa menjawab pertanyaan dengan kesalahan yang sama, seperti yang ditunjukkan pada Gambar 1b. Ini membuktikan bahwa siswa tidak tahu jawabannya dan tidak yakin. Dia lebih suka menyalin jawaban teman daripada menemukan jawabannya sendiri. 
Situasi tersebut diperkuat berdasarkan hasil observasi dan wawancara dengan guru matematika SMPN 1 Hiliserangai Kelas VIII tentang keterampilan mereka dalam memahami konsep matematika. Siswa belum mampu memprediksi konsep dan mengkategorikan sesuatu menurut atribut tertentu menurut konsep tersebut. Di bawah ini adalah beberapa contoh dan contoh konsep yang sedang kita pelajari.

Pemahaman konsep penting untuk belajar matematika secara bermakna, tentunya para guru mengharapkan pemahaman yang ingin dicapai siswa tidak terbatas pada pemahaman yang bersifat menghubungkan (Fahrudin, dkk, 2018; Agustina, 2016; Tetiwar \& Appilembang, 2018) . Pemahaman terhadap konsep menjadi bagian yang sangat penting dalam proses belajar dan memecahkan masalah, baik dalam proses belajar itu sendiri maupun dalam kehidupan nyata. Pemahaman konsep bukan hanya sekedar mengingat fakta atau menghafalkan konsep-konsep yang ada, akan tetapi yang sangat penting dalam pemahaman konsep siswa dituntutuntuk menemukan konsep, membangun konsep dan menggunakan konsep tersebut untuk memecahkan permasalahan yan ada. Memahami konsep matematika berarti menjelaskan keterkaitan algoritma antar konsep, dan mengaplikasikan konsep atau algoritma secara luwes, akurat, efisien, dan tepat dalam pemecahan masalah (Asma \& Lubis, 2017; Amrullah, 2014; Sarumaha, Harefa, \& Zagoto, 2018; Zagoto, 2018).

Maka perlu dicarikan solusi untuk mengatasi permasalah tersebut sehingga pembelajaran matematika menjadi bermakna, mampu mengembangkan kemampuan matematis siswa serta pembelajaran tidak lagi terpusat pada guru. Salah satu usaha yang bisa dilakukan pada proses belajar dalam peningkatan pemahaman konsep matematis siswa ialah menggunakan pendekatan Realistic Matematics Education (RME). RME ialah pendekatan yang memandang matematika sebagai suatu kegiatan manusia (human activities), dan belajar matematika berarti bekerja dengan matematika (doing matematic) (Karaca, Yetim \& Ozkaya, 2017; Wijaya, 2012). Pendekatan ini dikembangkan oleh Freudenthal Institute di Belanda sejak lebih dari tiga puluh tahun yang lalu dan menunjukkan hasil yang lebih baik. Pendekatan RME adalah bentuk pembelajaran yang menggunakan kegiatan pembelajaran dunia nyata untuk menyoroti kegiatan siswa untuk mencari, menemukan, dan membangun pengetahuan yang dibutuhkan sehingga pembelajaran lebih berpusat pada siswa. Artinya ada keterkaitan antara konsep matematika dengan pengalaman siswa sehari-hari (Jarmita, \& Hazami, 2013; Agustina, 2016). Guru tidak menjadi satu- satunya sumber belajar karena dengan pendekatan RME siswa diberi kesempatan untuk membangun pengetahuan sendiri.

\section{METODE}

Jenis penelitian termasuk semi eksperimental. Penelitian terdiri dari dua kelompok, kelompok eksperimen yang diberi perlakuan dengan pendekatan RME, dan pembelajaran konvensional yang digunakan di kelas kontrol. Variabel penelitian ini meliputi (1) variabel bebas, pendekatan pembelajaran dengan RME, (2) variabel terikat, pemahaman konsep matematika siswa. Populasi dalam penelitian ini adalah siswa kelas VIII SMP Negeri 1 Hiliserangkai Tahun Pelajaran 2019/2020. Sampel penelitian adalah kelas VIIIA sebagai kelas eksperimen dan kelas VIIIC sebagai kelas kontrol.

Hipotesis dalam penelitian ini adalah

1. Pemahaman konsep matematika siswa yang mengikuti pembelajaran dengan pendekatan RME lebih tinggi dari siswa yang mengikuti pembelajaran konvensional.

2. Pemahaman konsep matematika siswa berkemampuan awal tinggi yang mengikuti pembelajaran dengan pendekatan RME lebih tinggi dari siswa yang mengikuti pembelajaran konvensional. 
3. Pemahaman konsep matematika siswa berkemampuan awal sedang yang mengikuti pembelajaran dengan pendekatan RME lebih tinggi dari siswa yang mengikuti pembelajaran konvensional.

4. Pemahaman konsep matematika siswa berkemampuan awal rendah yang mengikuti pembelajaran dengan pendekatan RME lebih tinggi dari siswa yang mengikuti pembelajaran konvensional.

5. Terdapat interaksi antara pendekatan pembelajaran dan kemampuan awal dalam mempengaruhi pemahaman konsep matematis siswa.

\section{HASIL DAN PEMBAHASAN}

Data hasil tes pemahaman konsep, kemampuan pemecahan masalah dan disposisi matematis siswa yang berkemampuan awal tinggi, sedang, dan rendah pada kelas eksprimen dan kelas kontrol dideskripsikan menurut jumlah $(\mathrm{N})$, nilai tertinggi $\left(\mathrm{X}_{\text {maks }}\right)$, nilai terendah $\left(\mathrm{X}_{\mathrm{min}}\right)$, rata-rata $(\bar{x})$ dan simpangan baku (s) pada Tabel 1 berikut.

Tabel 1. Deskripsi Data Pemahaman Konsep Siswa Berkemampuan Awal Tinggi, Sedang, dan Rendah pada Kelas Eksprimen dan Kelas Kontrol

\begin{tabular}{|c|c|c|c|c|c|c|}
\hline \multirow{3}{*}{ Kelas } & \multirow{2}{*}{$\begin{array}{c}\text { Kemampuan } \\
\text { Awal }\end{array}$} & \multicolumn{5}{|c|}{ Pemahaman Konsep } \\
\cline { 3 - 7 } & $\mathrm{N}$ & $\bar{X}$ & $\begin{array}{c}\text { Simp. } \\
\text { Baku }\end{array}$ & $\mathrm{X}_{\text {maks }}$ & $\mathrm{X}_{\text {min }}$ \\
\hline \multirow{4}{*}{ Eksperimen } & Tinggi & 6 & 13 & 1,91 & 15 & 10 \\
\cline { 2 - 7 } & Sedang & 16 & 10,9 & 2,19 & 14 & 6 \\
\cline { 2 - 7 } & Rendah & 5 & 8,6 & 2,94 & 13 & 5 \\
\cline { 2 - 7 } & $\sum$ & $\mathbf{2 7}$ & $\mathbf{1 0 , 8}$ & $\mathbf{2 , 6 3}$ & $\mathbf{1 5}$ & $\mathbf{5}$ \\
\hline \multirow{3}{*}{ Kontrol } & Tinggi & 5 & 11,2 & 2,79 & 14 & 8 \\
\cline { 2 - 7 } & Sedang & 17 & 6,06 & 1,39 & 8 & 4 \\
\cline { 2 - 7 } & Rendah & 6 & 5,17 & 2,41 & 7 & 0 \\
\cline { 2 - 7 } & $\sum$ & $\mathbf{2 8}$ & $\mathbf{6 , 7 8}$ & $\mathbf{2 , 8 6}$ & $\mathbf{1 4}$ & $\mathbf{4}$ \\
\hline
\end{tabular}

\section{a. Pemahaman Konsep Matematis Siswa Kelas Eksprimen dan Kelas Kontrol}

Pada Tabel 1 terlihat bahwa rata-rata pemahaman konsep matematis siswa yang mengikuti pembelajaran dengan pendekatan $R M E$ lebih tinggi daripada rata-rata siswa yang mengikuti pembelajaran konvensional. Berdasarkan data simpangan baku maka pemahaman konsep matematis siswa yang mengikuti pembelajaran konvensional lebih beragam dibandingkan yang mengikuti pembelajaran dengan pendekatan $R M E$ karena simpangan baku pemahaman konsep matematis siswa kelas kontrol lebih besar daripada kelas ekspermen. Nilai maksimum pemahaman konsep matematis untuk kelas eksprimen lebih tinggi dibandingkan dengan kelas kontrol. Sedangkan nilai minimum pemahaman konsep matematis untuk kelas eksprimen juga lebih tinggi dibandingkan dengan kelas kontrol. Untuk lebih jelasnya, perbedaan skor rata-rata pemahaman konsep matematis siswa kelas eksperimen dan kelas kontrol dapat dilihat pada Gambar 2. 


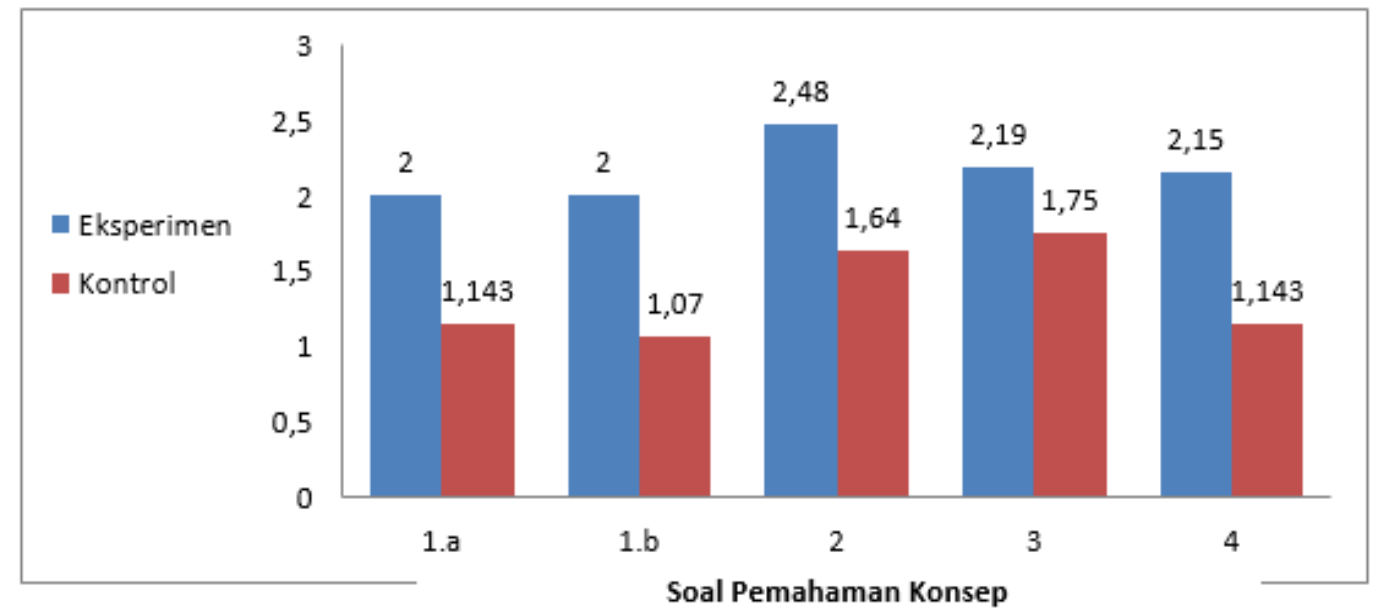

Gambar 2. Rata-Rata Skor Setiap Soal Pemahaman Konsep Matematis Siswa Kelas Eksperimen dan Kontrol

b. Pemahaman Konsep Matematis Siswa Berkemampuan Awal Tinggi, Sedang, dan Rendah Kelas Eksperimen dan Kontrol

Pada Tabel 1 terlihat bahwa di kelas eksperimen rata-rata pemahaman konsep matematis siswa berkemampuan awal tinggi, sedang dan rendah lebih tinggi daripada kelas kontrol. Berdasarkan data simpangan baku maka pemahaman konsep matematis siswa berkemampuan awal tinggi kelas kontrol lebih beragam daripada kelas eksperimen karena simpangan baku pemahaman konsep siswa berkemampuan awal tinggi kelas kontrol lebih tinggi daripada kelas eksperimen. Pemahaman konsep matematis siswa berkemampuan awal sedang dan rendah kelas eksperimen lebih beragam daripada kelas kontrol karena simpangan baku siswa berkemampuan awal sedang dan rendah kelas eksperimen lebih tinggi daripada kelas kontrol. Skor maksimum pemahaman konsep matematis siswa berkemampuan awal tinggi, sedang dan rendah kelas eksperimen lebih tinggi dibandingkan dengan kelas kontrol. Skor minimum pemahaman konsep matematis siswa berkemampuan awal tinggi, sedang dan rendah kelas eksperimen lebih tinggi daripada kelas kontrol.

Berdasarkan uji persyaratan analisis maka hipotesis 2, 3, 4, diuji dengan menggunakan uji t. Hipotesis 1 diuji dengan menggunakan uji Mann-Whitney U.

1. Hipotesis Pertama

Taraf signifikansi pertama adalah 0,000. Karena taraf signifikansi lebih kecil dari $\alpha$ $=0,05$ berarti tolak $\mathrm{H}_{0}$. Dapat disimpulkan pemahaman konsep matematis siswa yang mengikuti pembelajaran dengan pendekatan RME lebih tinggi daripada siswa yang mengikuti pembelajaran konvensional.

2. Hipotesis Kedua

Taraf signifikansi kedua adalah 0,141 . Karena taraf signifikansi lebih besar $\alpha=$ 0,05 berarti terima $\mathrm{H}_{0}$. Dapat disimpulkan bahwa Dapat disimpulkan pemahaman konsep matematis siswa berkemampuan awal tinggi yang mengikuti pembelajaran dengan pendekatan RME tidak lebih tinggi daripada siswa yang mengikuti pembelajaran konvensional.

3. Hipotesis Ketiga

Taraf signifikansi ketiga adalah 0,000. Karena taraf signifikansi lebih kecil $\alpha=$ 0,05 berarti tolak $\mathrm{H}_{0}$. Dapat disimpulkan bahwa pemahaman konsep matematis siswa berkemampuan awal sedang yang mengikuti pembelajaran dengan pendekatan RME lebih tinggi daripada siswa yang mengikuti pembelajaran konvensional. 


\section{Hipotesis Keempat}

Taraf signifikansi keempat adalah 0,043. Karena taraf signifikansi lebih kecil $\alpha=$ 0,05 berarti tolak $\mathrm{H}_{0}$. Dapat disimpulkan bahwa pemahaman konsep matematis siswa berkemampuan awal rendah yang mengikuti pembelajaran dengan pendekatan RME lebih tinggi daripada siswa yang mengikuti pembelajaran konvensional.

5. Hipotesis Kelima

Uji hipotesis kelima ini adalah untuk mengetahui apakah terdapat interaksi antara pendekatan pembelajaran dan tingkat kemampuan awal siswa terhadap pemahaman konsep matematis siswa. Berdasarkan grafik diatas terlihat bahwa plot yang didapat tidak bertemu (berinteraksi), maka dapat disimpulkan tidak terdapat interaksi antara pendekatan dan kemampuan awal siswa dalam mempengaruhi pemahaman konsep matematis siswa.

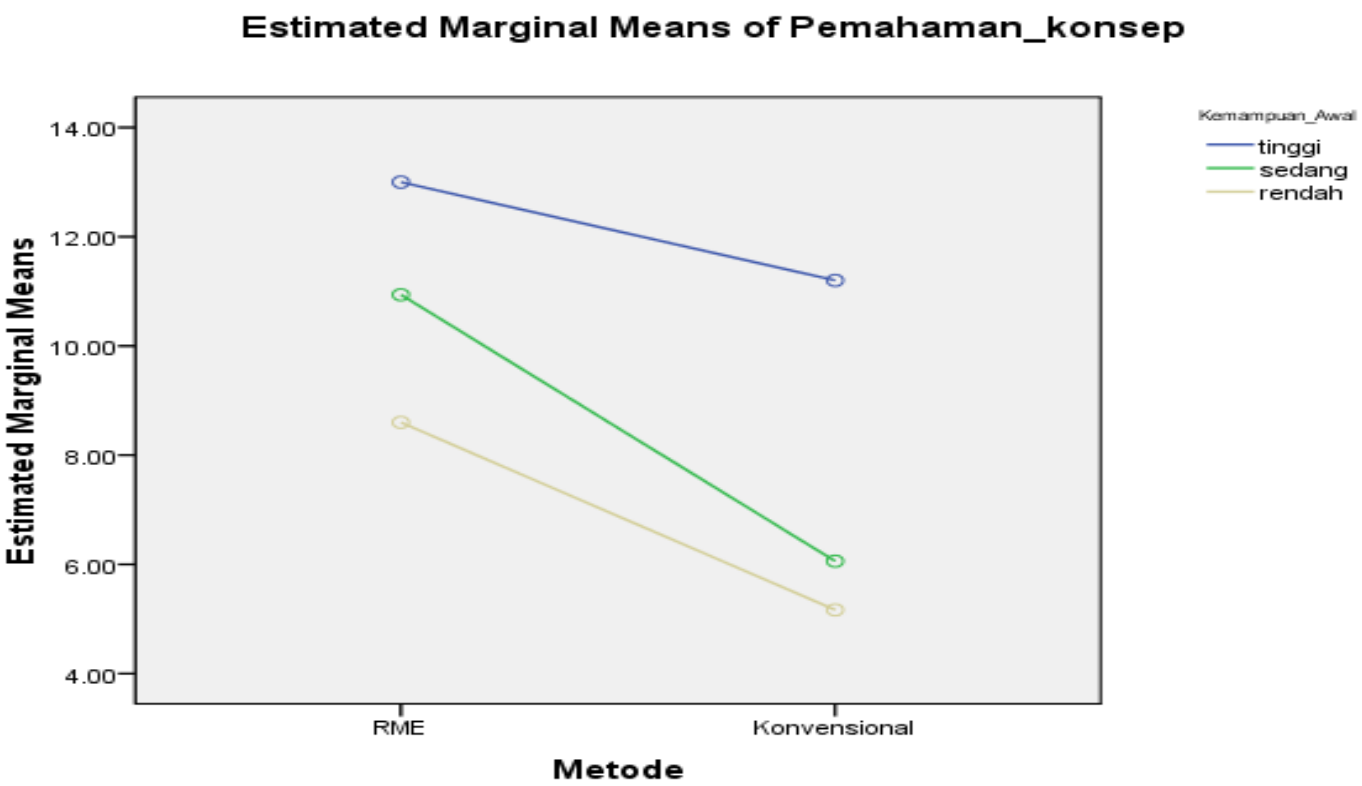

Gambar 3. Interaksi Pemahaman Konsep Matematis dan Kemampuan Awal Siswa

\section{SIMPULAN}

Berdasarkan hasil penelitian yang dikemukakan di atas dapat diketahui bahwa penggunaan pendekatan RME dalam pembelajaran matematika sangat efektif untuk meningkatkan hasil belajar terutama pada pemahaman konsep matematis siswa terutama yang berkemampuan awal sedang dan rendah. Kelebihan penggunaan pendekatan RME dalam pembelajaran matematika adalah pada penggunaan konteks yang langsung berkaitan dengan kehidupan sehari-hari siswa, dan pembelajaran yang langsung memeberikan kesempatan bagi setiap siswa untuk mengkonstruksi pengetahuannya untuk menemukan konsep atau rumus matematika yang akan digunakan. Hal ini menjadikan pembelajaran bermakna, menyenangkan dan tidak mudah terlupakan. Pendekatan RME dalam pembelajaran matematika mampu meningkatkan hasil belajar siswa terutama pada pemahaman konsep matematis siswa lebih tinggi dari pada pembelajaran konvensional. Bagi peneliti selanjutnya diharapkan hasil penelitian ini dapat menjadi salah satu dasar atau masukan dalam melakukan penelitian yang releven.

\section{DAFTAR PUSTAKA}

Agustina, L. (2016). Upaya Meningkatkan Kemampuan Pemahaman Konsep dan Pemecahan Masalah Matematika Siswa SMP Negeri 4 Sipirok Kelas VII melalui Pendekatan 
$\begin{array}{lllll}\text { Matematika } & \text { Realistik } & \text { (PMR). } & \text { Eksakta, } & \text { 1(1): }\end{array}$ http://jurnal.umtapsel.ac.id/index.php/eksakta/article/view/49.

Amrullah, A. L. (2014). Penerapan Pendekatan Realistic Mathematics Education Untuk Meningkatkan Hasil Belajar Siswa Pada Materi Soal Cerita Tentang Himpunan Di Kelas VII MTSN Palu Barat. Jurnal Eleketronik Pendidikan Matematika Tadulako, 2(1), 1-11.

Asma \& Lubis, M. S. (2017). Upaya Meningkatkan Kemampuan Pemahaman Konsep Siswa Kelas VIII Mts. Al-Ilhamiyah Sidomulyo menggunakan Pendekatan Realistic Mathematics Education (RME) pada Sub Materi Pokok Kubus dan Balok Tahun Ajaran 2016/2017. AXIOM: Jurnal Pendidikan dan Matematika, 6(1): halaman. 1-12. http://jurnal.uinsu.ac.id/index.php/axiom/article/view/759.

Dakhi, O., Jama, J., Irfan, D., Ambiyar, Ishak. (2020). Blended Learning: A 21st Century Learning Model At College. International Journal Of Multi Science, 1(8), 50-65.

Fahrudin, A. G., Zuliana, E., \& Bintoro, H. S. (2018). Peningkatan Pemahaman Konsep Matematika Melalui Realistic Mathematic Education Berbantu Alat Peraga BONGPAS. Anargya: Jurnal Ilmiah Pendidikan Matematika. 1(1): halaman. 14-20. https://jurnal.umk.ac.id/index.php/anargya/article/view/2280.

Fajra, M., Suparno, Sukardi, Ambiyar, Novalinda, R. (2020). Project-Based Learning Innovation To Improve The Suitability Of Productive Competencies In Vocational School With The Needs Of The World Of Work. International Journal Of Multi Science, 1(8), 1-11.

Jarmita, N. \& Hazami. (2013). Ketuntasan Hasil Belajar Siswa Melalui Pendekatan Realistic Mathematics Education (RME) Pada Materi Perkalian. Jurnal Ilmiah DIDAKTIKA Februari 2013, 13(2), 212-222.

Karaca., Yetim, S., \& Ozkaya, A. (2017). The Effects of Realistic Mathematics Education on Student's Math Self Reports in Fifth Grades Mathematics Course, dalam IJCI, Vol.9, No.1

Masril, M., Dakhi, O., Nasution, T., Ambiyar. (2020). Analisis Gender Dan Intellectual Intelligence Terhadap Kreativitas. Edukasi: Jurnal Pendidikan, 18 (2), 182-191. https://doi.org/10.31571/edukasi.v18i2.1847

Sarumaha., Harefa, Darmawan., Zagoto, Maria M. (2018). "Upaya Meningkatkan Kemampuan Pemahaman Konsepgeometri Transformasi Refleksi Siswa Kelas Xii-Ipa-B Sma Kampus Telukdalam Melalui Model Pembelajaran Discoverylearning Berbantuan Media Kertas Milimeter", Jurnal Education And Development, Vol. 6, no. 1, p. 90, oct. 2018. Https://doi.org/10.37081/ed.v6i1.668

Tetiwar, T., \& Appulembang, O. D. (2018). Penerapan Metode Peer Tutoring Untuk Meningkatkan Pemahaman Konsep Materi Perkalian Bersusun Pada Siswa Kelas III SD. Scholaria: Jurnal Pendidikan dan Kebudayaan, 8(3), 302-308.

Wijaya, Ariyadi. 2012. Pendidikan Matematika Realistik; Suatu Alternatif Pendekatan Pembelajaran Matematika. Yogyakarta: Graha Ilmu.

Zagoto, Maria M. \& Dakhi, O (2018). Pengembangan Perangkat Pembelajaran Matematika Peminatan Berbasis Pendekatan Saintifik Untuk Siswa Kelas XI Sekolah Menengah Atas. Jurnal Review Pendidikan dan Pengajaran, 1(1), 157-170.

Zagoto, Maria M. (2018). Pengembangan Perangkat Pembelajaran Matematika Berbasis Realistic Mathematic Educations Untuk Siswa Kelas V Sekolah Dasar, Jurnal Education And Development, vol. 3, no. 1, p. 53, Feb. 2018. https://doi.org/10.37081/ed.v3i1.139 